\title{
ISTILAH DALAM FORUM JUAL-BELI DARING DI MEDIA SOSIAL FACEBOOK
}

\section{TERMS IN ONLINE TRADING FORUM IN FACEBOOK}

\author{
R. Hery Budhiono \\ Balai Bahasa Kalimantan Tengah \\ ralph.herybudhiono@kemdikbud.go.id
}

\begin{abstract}
ABSTRAK
Jual-beli daring setakat ini kian menjamur dan menjadi tren tersendiri pada era teknologi informasi. Cara berjualan tradisional terlihat kuno jika dibandingkan dengan berjualan daring. Maraknya lapak daring di media sosial Facebook memunculkan media komunikasi. Bahasa yang digunakan memiliki ciri dan karakter tersendiri. Penelitian ini mencoba mengupas istilah-istilah yang digunakan dalam forum jual-beli daring di Facebook. Tujuannnya ialah mengidentifikasi dan mendefinisikan istilah-istilah yang digunakan secara kontekstual. Penelitian ini merupakan penelitian deskriptif kualitatif. Data diambil dari dua grup di Facebook, yaitu grup Indonesian Casuals dan Clobber Casual Indonesia. Berdasarkan analisis didapati bahwa ada beberapa istilah asing yang digunakan, misalnya bidding, dead stock, mint condition, dan sebagainya. Kode-kode terbatas ini bagi mereka merupakan pembeda dari komunitas lain.
\end{abstract}

Kata kunci: istilah, teks, konteks, sosiolinguistik, media sosial, Facebook

\begin{abstract}
Online trading is spreading world wide nowadays. It becomes such a trend in this information technology era. Traditional way of trading looks old-fashioned when it is compared with its new model. This bombing phenomena of online trading encourages the rise of new restricted codes used by its participants. It has a certain typical characterictics. This work tries to indentify dan define terms used within contextually. It is a qualitative descriptive research. The data come from two dominant grups in Facebook, Indonesian Casuals and Clobber Casual group. The writer found that there are many foreign terms used by the participants of the whole groups. For the community, these codes differentiate them from any other communities

Keywords: terms, text, context, sociolinguistics, social media, Facebook
\end{abstract}

\section{PENDAHULUAN}

Seiring dengan pesat berkembangnya teknologi, interaksi antarmanusia menjadi semakin intens. Kenaikan intensitas interaksi tersebut didorong oleh semakin kompleks dan mendesaknya keperluan akan komunikasi dan mendesaknya pemenuhan kebutuhan diri. Macam ragam cara interaksi pun kemudian berkembang sesuai dengan keperluan dan situasi yang memayungi dan melingkupinya.

Tidak seperi zaman dahulu dan masa sebelum teknologi berkembang pesat, interaksi manusia berkaitan erat dengan kesintasan dan adanya keperluan 
Tuah Talino

Tahun XIV Volume 14 Nomor 1 Edisi 31 Juli 2020

ISSN 0216-079X E-ISSN 2685-3043

Balai Bahasa Kalimantan Barat

pemenuhan kebutuhan informasi. Pada era kini, bahkan transaksi perdagangan pun meninggalkan model dan metode lama yang mengharuskan penjual dan pembeli bersemuka di dunia nyata. Model dan metode lama itu kini menjelma menjadi model interaksi virtual. Penjual dan pembeli tidak lagi wajib bersemuka untuk melakukan aktivitas perniagaan. Aktivitas niaga tidak lagi dilakukan per orang secara nyata, tetapi secara virtual.

Namun demikian, cara-cara atau teknik berdagang model konvensional, misalnya tawar-menawar, tidaklah hilang begitu saja. Tawar-menawar tetap ada dengan cara dan media yang berbeda. Kegiatan pedagang dalam menawarkan barang dagangannya dan pembeli dalam melihat-lihat dan kemudian menawar harga barang idamannya semakin beraneka ragam modus dan medianya.

Beragamnya media sosial yang dapat diakses menimbulkan beragam modus pedagang dalam menjajakan dagangannya. Salah satu media sosial yang banyak dipilih oleh sebagian besar pedagang daring ialah Facebook. Facebook merupakan media sosial yang berdiri sejak tahun 2004 dan diinisiasi oleh Mark Zuckerberg. Kini Facebook memiliki pengguna aktif sebanyak 2,27 miliar orang di seluruh dunia per Februari 2019. Di Indonesia saja pengguna aktif Facebook mencapai 150 juta orang per Februari 2019. Dapat dibayangkan potensi pasar pengguna aktif Facebook di Indonesia sangat besar. Tidak heran jika banyak pedagang konvensional yang mengalihkan atau mengubah gaya berdagangnya ke media sosial. Di samping tidak menuntut biaya operasional yang banyak, kesempatan berpromosi justru lebih luas di dunia maya karena jutaan pasang mata terus memantau.

Pada media sosial Facebook terdapat beberapa forum jual-beli (FJB) yang terbagi dalam beberapa kategori menurut jenis barang yang dijual. Salah satunya ialah FJB Indonesian Casuals (FJBIC) dan FJB Clobber Casual Indonesia (FJBCCI). FJBIC beranggotakan sebanyak 168.452 orang pengguna aktif, sedangkan FJBCCI beranggota 173.401 pengguna aktif per Maret 2019.

Sesuai dengan namanya, barang-barang yang dijual dalam kedua FJB itu berkisar pada pakaian dan aksesoris pakaian yang sifatnya kasual dan informal yang di dunia barat disebut street wear atau terrace wear. Salah satu item kasual yang memiliki banyak peminat ialah sepatu berjenis sneaker dan jaket kasual. Berbagai macam merek dan model sepatu serta jaket bertebaran dalam forum ini. Tidak heran jika peredaran uang dalam forum tersebut sangat besar dan menjadi pasar potensial yang tidak pernah lesu dan tidak pernah pula terpengaruh oleh segala macam krisis keuangan.

Beberapa penelitian tentang penggunaan register dalam media sosial dan internet secara umum pernah dilakukan. Karindra (2011) meneliti pola perilaku pengguna media sosial yang memiliki ketergantungan atau candu internet. Simpulan yang dirangkumnya antara lain pengguna internet cenderung bersikap introver sehingga enggan bersemuka dengan orang lain, terutama orang yang dikenalnya di media sosial. Simpulan lain ialah pengguna internet semacam ini justru lebih terbuka jika diajak berinteraksi di dunia maya dibandingkan dengan interaksi di dunia nyata. Ini beralasan mengingat ia merasa aman berinteraksi di dunia maya karena identitas dan jati dirinya tidak diketahui oleh orang lain secara langsung. 
Tuah Talino

Tahun XIV Volume 14 Nomor 1 Edisi 31 Juli 2020

ISSN 0216-079X E-ISSN 2685-3043

Balai Bahasa Kalimantan Barat

Penelitian lain dilakukan oleh Dhianari tahun 2011. Ia meneliti ragam bahasa yang digunakan dalam Kaskus, sebuah situs sosial yang dirintis oleh diaspora Indonesia di Amerika. Bahasa yang digunakan dalam media sosial itu digolongkan ke dalam jenis singkatan, akronim, pelesetan, penyederhanaan lafal, dan sebagainya. Atmahardianto (2010) meneliti register dalam Kaskus. Ciri-ciri register yang dapat disimpulkannya ialah penghilangan afiks (elipsis), pemendekan bentuk, dan pemakaian bentuk singkatan. Thufail (2017) mengupas tentang register dalam forum jual-beli ponsel di Facebook. Fungsi register itu, menurutnya, ialah untuk meyakinkan, menamai, dan merahasiakannya dari komunitas lain. Muttaqien (2016) pernah meneliti jargon komunitas jual-beli jersey di internet. Ia menyimpulkan bahwa penggunaan singkatan dan akronim sangat dominan dalam ragam transaksional ini. Beberapa jargon berlaku pula di dalam forum jual-beli yang lain, tidak terbatas hanya pada jersey.

Berdasarkan beberapa studi pustaka tersebut dapatlah dianggap relatif jarang studi tentang istilah yang digunakan dalam forum jual-beli sepatu dan pakaian di Facebook. Berdasarkan asumsi itu kemudian penulis mengadakan penelitian tentang apa dan bagaimana istilah khusus yang digunakan dalam forum jual-beli FJBIC dan FJBCCI di Facebook.

Penelitian ini mendeskripsikan berbagai macam istilah khusus yang sering dan selalu digunakan pedagang dan pembeli ketika berinteraksi di forum, khususnya sepatu jenis sneaker. Analisis akan dipusatkan pada apa dan bagaimana makna istilah tersebut secara kontekstual dan apa dampak penggunaan register itu bagi pengguna atau anggota forum.

Penelitian ini memiliki manfaat praktis diantaranya menambah pengetahuan pembaca terhadap istilah dan register yang digunakan dalam forum jual-beli di Facebook. Pengetahuan tentang hal tersebut penting ketika mereka ingin menggunakan media sosial itu untuk bertransaksi. Secara teoretis penelitian ini dapat memperkaya rujukan penelitian dalam bidang sosiolinguistik.

Untuk memudahkan analisis terhadap masalah penelitian ini dan untuk membatasi ruang lingkup jenis data, penelitian ini hanya mengambil data dari dua forum jual-beli, yaitu FJBIC dan FJBCCI. Data yang diambil merupakan register dan istilah yang digunakan dalam iklan atau interaksi pedagang-pembeli untuk barang berjenis sepatu sneaker.

Penelitian ini mencakup ranah sosiolinguistik meskipun sebagian termasuk dalam wilayah linguistik fungsional yang memusatkan diri pada teks dan konteks yang pertama kali diajukan oleh Malinowski. Dalam kegiatan penelitian itu Malinowski menemukan beberapa register atau istilah khusus yang digunakan dalam kegiatan memancing ikan yang dilakukan atau merupakan kebiasaan masyarakat setempat. Istilah itu tidak ditemukannya di bidang lain selain yang berhubungan memancing dengan segala aspeknya. Firth kemudian merumuskan secara lebih detail konteks situasi ke dalam beberapa terminologi, yaitu pelibat (partisipan), tindakan (verbal dan nonverbal), ciri-ciri situasi lain yang relevan, dan dampak. Gagasan Firth ini kemudian dikembangkan oleh Hymes dengan teori SPEAKING-nya, salah satu parafrasa teori Firth yang paling terkenal hingga kini (Halliday \& Hasan, 1992: 11). Tesis kedua ilmuwan yang bersinambung tersebut 
Tuah Talino

Tahun XIV Volume 14 Nomor 1 Edisi 31 Juli 2020

ISSN 0216-079X E-ISSN 2685-3043

Balai Bahasa Kalimantan Barat

membawa Halliday kemudian merumuskan tiga ciri konteks situasi, yaitu medan wacana (field), pelibat (tenor), dan sarana (mode) (Halliday \& Hasan, 1992: 16).

Medan wacana mengacu kepada hal yang sedang terjadi dan sifat aktivitas yang sedang berlangsung. Pelibat mengacu kepada orang-orang yang terlibat dalam situasi itu, sifat mereka, kedudukan, dan perannya. Sarana mengacu kepada bagian yang dijalankan oleh bahasa, simbol teks, cara menyampaikan, dan retorikanya. Adanya konteks situasi dan pelibat serta sarana dan keterlibatan ketiganya membentuk atau menimbulkan adanya ragam istilah khusus dalam suatu bidang tertentu yang dikenal sebagai register.

Register merupakan konsep semantik yang dapat didefinisikan sebagai susunan makna yang dihubungkan secara khusus dengan susunan situasi tertentu dari medan wacana, pelibat, dan sarana (Halliday \& Hasan, 1992: 53). Dalam register termasuk juga ungkapan dan singkatan. Register bergantung pada apa yang dikerjakan dan sifat kegiatan itu. Jadi, terdapat banyak sekali register yang digunakan orang tergantung dari pekerjaan atau kegiatan orang itu, berdagang, dokter praktik, penyuluhan, dan sifat kegiatannya, formal atau informal.

Berdasarkan uraian teoretis di atas dapatlah disimpulkan bahwa dalam melakukan aktivitasnya di dunia maya, berdagang, menawarkan sesuatu, mencari dan menawar barang dagangan, pedagang dan penjual sering melontarkan berbagai macam register atau istilah khusus yang bisa jadi hanya berlaku dalam forum itu. Pedagang dan pembeli merupakan pelibat, sedangkan sarananya ialah bahasa dalam media sosial. Sementara itu, wacana yang terjadi ialah wacana yang bersifat transaksional.

Sebagai sebuah jejaring sosial, situs media sosial menjadi ajang berkumpulnya berbagai individu dari kelas sosial yang berbeda. Mereka bergabung dan meleburkan diri dalam sebuah komunitas yang berbeda kelas sosial, tetapi setara dalam minat dan kesenangan. Anggota FJBIC dan FJBCCI tidak terkecuali merupakan kumpulan individu yang mengelompok dalam sebuah komunitas. Mereka secara tidak sadar terikat oleh satu minat dan kepentingan yang sama. Pendapat Gumperz sejalan dengan itu (Wijana \& Rohmadi, 2006: 23).

Komunitas dalam hal ini kumpulan orang yang memiliki kepentingan yang sama, cenderung membedakan diri dari komunitas lain. Perbedaan itu meliputi atribut yang dipakai dan register serta istilah-istilah khusus yang digunakan. Sumarsono dan Partana (2002: 43) menyatakan bahwa golongan yang memiliki kesamaan dalam kategori sosial tertentu dapat diklasifikasikan sebagai kelas sosial.

Komunitas atau kelompok sosial yang mengguyup berdasarkan satu atau beberapa persamaan minat dan keperluan dalam kajian sosiolinguistik mendapat perhatian yang serius sebagai salah satu variabel yang menentukan ragam bahasa. Ragam bahasa yang digunakan oleh suatu kelompok dapat saja berbeda dari ragam bahasa kelompok lainnya. Dalam hal inilah teks dan konteks berkelindan membentuk kesatuan yang tidak terpisahkan, satu memengaruhi yang lain.

Chambers bahkan mengatakan bahwa beberapa kelompok sosial dibedakan tidak menurut kelas sosialnya, tetapi oleh variasi kebahasaannya (2001: 7-8). Variasi linguistik inilah yang kemudian digunakan untuk mendemarkasi diri atau mengekslusifkan diri dan membedakannya dari kelompok sosial yang lain. 
Kelompok ini kemudian menjadi jejaring dan memiliki pola interaksi komunikasi tersendiri dan spesifik. Mirip sebuah masyarakat mini, menurut Bott, jejaring ini juga memiliki norma dan hukum yang niscaya harus dipatuhi oleh anggota di dalamnya (Chambers, 2001: 67).

Dalam hal ini Saville-Troike mengemukakan bahwa hubungan antara bahasa dan identitas sosial bersifat timbal balik: perasaan kedekatan atau karib tidaknya relasi memicu kesetaraan dan ketidaksetaraan dalam pola berbahasa; sementara itu kesamaan dalam berbahasa akan memunculkan solidaritas (SavilleTroike, 1989: 264).

Dikatakan di atas bahwa sebuah kelompok sosial atau komunitas tertentu merupakan miniatur masyarakat. Dengan demikian, hukum dan norma yang berlaku dalam sebuah masyarakat juga berlaku dalam kelompok tersebut, tetapi dalam ranah dan tataran yang lebih eksklusif dan terbatas. Norma dan hukum tersebut merupakan kendali internal supaya semua anggota grup merasa nyaman dan aman dalam berinteraksi dan bertransaksi dengan sesama anggota. Sebaliknya, norma dan hukum tersebut menjadi pemagar atau pembatas antara grup atau komunitas dan dunia di luar mereka.

Untuk kepentingan internal dan mengamankan diri dari intervensi pihak eksternal yang dapat mengganggu kenyamanan, suatu komunitas atau guyup biasanya memiliki ragam komunikasi tersendiri. Ragam spesifik ini digunakan hanya di dalam kalangan sendiri dan biasanya tidak banyak orang luar yang memahaminya. Namun demikian, seiring dengan masifnya pengaruh media dan semakin memapar serta memajannya kode-kode milik suatu komunitas tertentu, ciri spesifik bahasa mereka juga ikut menyebar dan meluas. Dampaknya, komunikasi internal mereka dapat dipahami dan dimengerti orang lain. Oleh Bernstein, kode seperti ini disebut sebagai kode terbatas (Sumarsono \& Partana, 2002: 54).

Satu di antara ragam bahasa yang sudah cukup populer dan beredar luas ialah ragam bahasa walikan yang merakyat di daerah Malang. Orang Malang atau yang mengidentikkan dan melambangi dirinya dengan kera ngalam (berasal dari istilah arek Malang yang ejaannya secara sengaja dibalik) menggunakan bahasa yang ejaannya terbalik. Memang tidak semua kata atau istilah, tetapi terbatas pada kata-kata sapaan yang sifatnya mengakrabkan pergaulan, strukturnya dibalik. Kata-kata seperti Mas, iya, aku, dan saya dan beberapa kata lain dibalik ejaannya menjadi sam, ayi, uka, dan ayas. Kode-kode seperti ini relatif sudah menyebar dan sudah banyak orang luar komunitas yang memahaminya sehingga tidak lagi dianggap ciri spesifik komunitas yang menuturkannya.

\section{METODE}

Penelitian ini merupakan penelitian deskriptif-kualitatif. Menurut Strauss dan Corbin dalam Wignjosoebroto (Suyanto \& Sutinah, 2005: 193), ada tiga komponen utama dalam penelitian kualitatif, yaitu data, prosedur analitisinterpretatif, dan laporan verbal.

Tahapan penelitian yang disarankan oleh Sudaryanto(2015: 6-8) diterapkan dalam melaksanakan penelitian ini, yaitu penyediaan data, analisis, dan penyajian hasil analisis. Sumber data ialah media sosial Facebook dan dua grup jual-beli di 
dalamnya, yaitu Forum Jual-Beli Indonesian Casuals (FJBIC) dan Forum JualBeli Clobber Casual Indonesia (FJBCCI). Data percakapan pedagang dan pembeli yang berisi ragam bahasa khas komunitas mereka di-capture dan dikumpulkan serta diklasifikasi sesuai dengan tujuan penelitian.

Tahapan yang dilaksanakan selanjutnya ialah analisis. Berdasarkan klasifikasi, istilah yang tidak memenuhi tujuan penelitian disisihkan. Analisis dilakukan secara kontekstual, yaitu menyertakan konteks percakapan tempat register atau istilah tersebut digunakan.

Tahapan analisis dan interpretasi data selanjutnya mengikuti anjuran Creswel (2003: 191-192), yaitu mengorganisasi data, membaca keseluruhan data, dan yang terakhir menginterpretasinya.

Tahap terakhir yang dilakukan ialah penyajian hasil analisis. Penyajian hasil analisis dilakukan secara naratif deskriptif dan diuraikan secara kualitatif.

\section{PEMBAHASAN}

Sebagai ajang bertemu semua anggota forum itu, FJBIC dan FJBCCI sebagian besar berisi aktivitas perniagaan seperti halnya pasar konvensional. Pasar konvensional yang dikesankan kumuh dan sumpek berpindah ke dunia maya tanpa adanya bentuk fisik pasar tersebut. Interaksi orang yang sebenarnya sangat intens dan ramai juga tidak tampak sebagai sebuah kegiatan perniagaan. Namun, perkembangan dunia perdagangan elektronik atau e-commerce dalam pasar ramai yang "sunyi" ini menyumbang pendapatan negara dan pertumbuhan ekonomi yang cukup signifikan.

FJBIC dan FJBCCI merupakan forum bertemunya pedagang dengan pembeli dan calon pembeli. Di sana mereka dapat menawarkan barang, mempromosikan, dan bahkan mencari barang idaman dengan membuat semacam iklan sederhana. Iklan ini secara konvensional kemudian disebut lapak. Anggota lain dapat sekadar berkomentar untuk meramaikan forum, atau bahkan menawarkan barang dagangan sendiri di "lapak" orang lain. Di sinilah kemudian berbagai komentar anggota forum tertumpah dengan berbagai istilah atau register di dalamnya. Banyaknya komentar dalam satu kiriman memengaruhi tampilan kiriman itu di halaman forum. Kiriman yang komentarnya sedikit biasanya "ditenggelamkan" oleh kiriman lain yang mempunyai banyak komentar. Berikut disampaikan beberapa contoh istilah dan register yang jamak digunakan dalam kedua forum itu.

\section{Irfan Muhamad Rivaldi \\ सto 32 mit ' :}

Ada yang masih inget dengan janji paman buat

ngasih give away?

Maaf kemaren paman lagi kalang kabut

nakmuda.

Udah di follow kan IG @sneakers_u_roots nya?

Pantengin aja nih, kita sesuai janji kok

Bakal ada give away ya walau 'retjeh" tapi

setidaknya in sha allah manfaat . 


\section{Revan Kusnaedi * FJB CLOBBER}

CASUAL INDONESIA

25 menit yang lalu : $B$

-WTB-WTB bantu temen.

-Bismillah-

- Ada dana 7xx bisa melar nyari utapes yg size

40 yg used gpp,sok yg lagi bu/jual butuh bisa

ditawarkan,butuh cepat.

- Lokasi:Bogor,Ciomas.

-Cod:Sekitar Bogor aja,kirim2 wajib ada

reputasi/rekber.

-Wa:089662592849

... Lihat Lainnya

\section{Cp company}

Rp 1.800 - Purwakarta

WTS/WTT

Hoodie Goggle Cp company

Size 14 setara M lokal

Good condition $95 \%$

Minus?klip nya doang sebelah bukan yg ori,ada di

picture

Price?1,8nego sampe jadi

Trade?Trade sama sepatu yg SETARA size $40^{2} / 3-41$..

Lihat Lainnya

\section{WTB}

Rp $2.500 \cdot$ Citayam

WTB Santai (utamain barang Like New/Used VVGC)

-1,1-1,3 = Alas Kaki Size 42 Jeans,Bermuda dII (No

Samba,SI,Stan Smith,Spezial, LA \&Kodachi)

-1000k = Penghangat Tubuh Size L (Marshall

Artist,MAstrum,Ellese DII)

$\cdot 200$ = BarrelBag Lonsdale ... Lihat Lainnya 


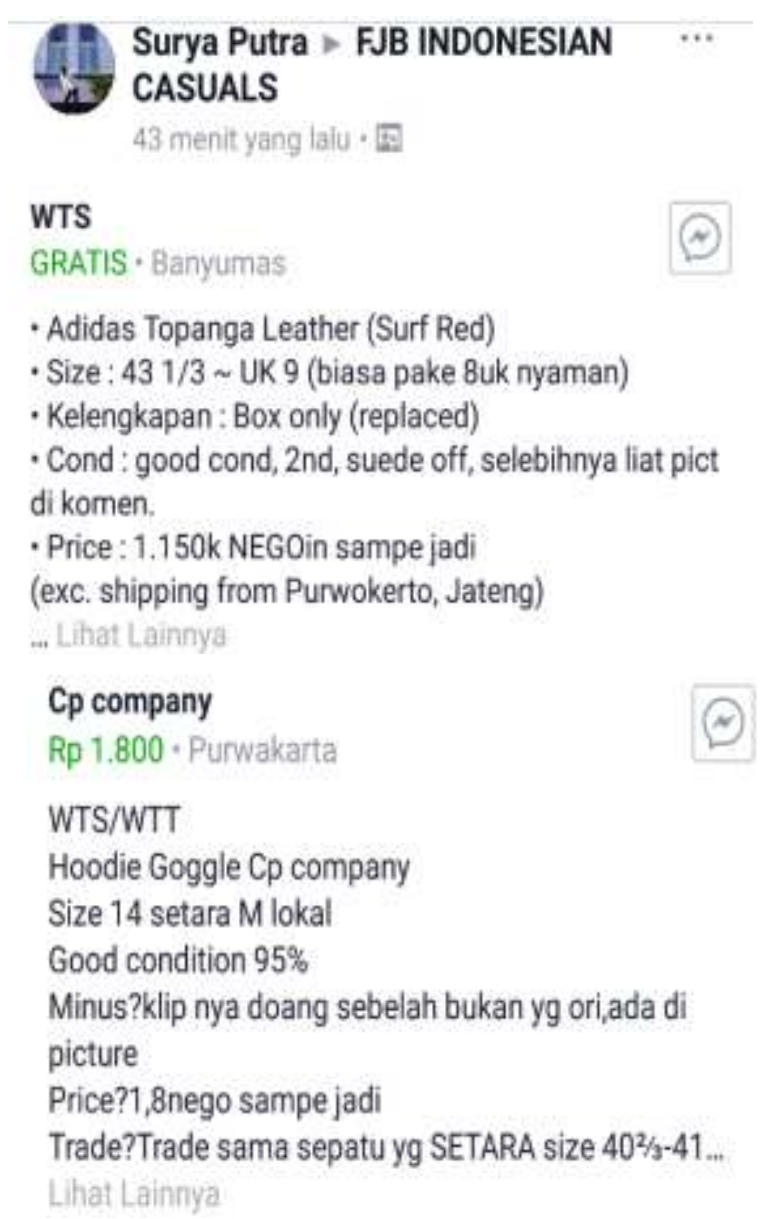

Pada contoh di atas dijumpai ada beberapa register yang digunakan, yaitu WTT, WTS, dan WTB. WTT merupakan kependekan dari want to trade. Trade dalam istilah ini mengacu kepada pertukaran barang yang setara baik kondisi fisik maupun ukurannya. Pedagang ingin menukarkan barangnya dengan barang yang setara baik jenis, ukuran, kondisi, maupun harganya. Namun, pada kenyataannya, WTT lebih sering ditanggapi dan ditindaklanjuti dengan aktivitas tukar-tambah barang. Sangat jarang dijumpai dalam konteks WTT ini pedagang menambahkan sejumlah dana, tetapi pembelilah yang lebih sering menambah dana. Namun, bagaimanapun juga karena adanya tawar-menawar di antara mereka, semua dapat berubah sesuai dengan keperluan dan kesepakatan kedua belah pihak.

WTS merupakan kependekan dari want to sell. Dalam konteks ini pedagang hanya ingin menjual dagangannya dan tidak menerima tukar-tambah. Dalam konteks WTS inilah biasanya kegiatan tawar-menawar barang terjadi secara tidak bersemuka. Teknik atau ragam cara menawar juga tidak jauh berbeda dari toko konvensional. Namun, karena tidak bersemuka, pedagang biasanya diminta untuk mengunggah foto dagangannya sedetail mungkin dan beresolusi tinggi atau high definition (HD).

Istilah WTB merupakan kependekan dari want to buy. Istilah ini merupakan iklan atau pemberitahuan dari calon pembeli bahwa ia mencari dan hendak 
Tuah Talino

Tahun XIV Volume 14 Nomor 1 Edisi 31 Juli 2020

ISSN 0216-079X E-ISSN 2685-3043

Balai Bahasa Kalimantan Barat

membeli barang tersebut. Dalam iklannya calon pembeli atau dalam hal ini anggota forum menjelaskan kriteria barang yang dicarinya, seperti jenis barang, merek, kondisi, dan dana yang dimilikinya. Pedagang yang memiliki barang yang sesuai dengan kriteria yang diajukan pembeli biasanya dengan serta merta memajang barang dagangannya. Namun, acap kali juga, pedagang lain memasang iklan yang tidak sesuai dengan kriteria barang yang dicari pembeli. Jika iklan WTB ini ramai dengan komentar yang berarti banyak ditinjau oleh anggota forum, iklan-iklan titipan ini banyak berjejalan mengisi forum.

Foto barang sangat penting bagi calon pembeli, apalagi barang berstatus bekas atau barang preloved. Barang yang merupakan barang bekas pakai wajib dijelaskan kondisi dan kekurangannya. Penjelasan dapat dilakukan lewat foto beresolusi tinggi atau dapat juga melalui deskripsi. Di sinilah kemudian unsur subjektivitas yang berkaitan dengan kondisi barang berlaku.

Subjektivitas yang dimaksud di sini ialah penilaian orang akan kondisi barang yang sama biasanya berbeda. Kondisi yang dianggap minus bisa saja dianggap wajar karena pemakaian oleh orang lain. Sebaliknya, kondisi wajar karena pemakaian bisa saja dinilai minus oleh calon pembeli. Transparansi dan keterangjelasan produk atau barang sangat penting di sini. Jika tidak sesuai deskripsi, dengan perjanjian yang dibuat sebelumnya, pembeli dibolehkan mengembalikan barang yang telah dibeli. Proses retur ini tentu saja memengaruhi reputasi pedagang.

Dalam contoh di atas juga tertera istilah give away. Istilah ini mengacu kepada semacam hadiah yang diberikan pedagang kepada semua orang yang beruntung. Biasanya yang berpeluang mendapatkan hadiah itu ialah mereka yang tergabung dalam grup jual-beli dimaksud. Acara give away ini biasanya dimaksudkan untuk meramaikan forum dan sekaligus meramaikan lapak pedagang itu dan dikaitkan dengan momen-momen tertentu. Semakin sering pedagang mengadakan give away semakin ramai pula lapaknya.

Dalam konteks kondisi barang yang dijual baik sepatu maupun pakaian, ada beberapa istilah yang digunakan untuk mendeskripsikan barang dimaksud, terutama barang bekas pakai. Istilah tersebut di antaranya dead stock (DS), near dead stock (NDS), very near dead stock (VNDS), good condition, very good condition (VGC), very very good condition (VVGC), best condition, dan like new.

Istilah DS mengacu kepada barang baru dan belum pernah dipakai, tetapi merupakan keluaran lama atau old stock dan tidak lagi diproduksi secara massal. Barang-barang DS biasanya hanya merupakan pajangan kolektor dan memang tidak pernah dipakai sama sekali, kecuali untuk fitting (mencocokkan ukuran) kaki saja. Barang-barang DS biasanya dimiliki oleh para kolektor yang memang seorang peminat sejati.

Barang NDS dan VNDS statusnya sama dengan DS, tetapi biasanya sudah pernah dipakai beberapa kali. Barang NDS dan VNDS biasanya masih tampak seperti baru dan tidak ada tanda-tanda bekas pemakaian. Biasanya pemilik hanya memakainya di lingkungan indoor atau dalam ruangan sehingga terhindar dari tanda atau kondisi bekas pakai. Barang berjenis DS, NDS, dan VNDS ini biasanya dilepas beserta kelengkapan bawaan yang terdiri atas dus atau boks, kertas pembungkus, dan tag atau label barang. 
Tuah Talino

Tahun XIV Volume 14 Nomor 1 Edisi 31 Juli 2020

ISSN 0216-079X E-ISSN 2685-3043

Balai Bahasa Kalimantan Barat

Barang yang berkategori good condition, VGC, VVGC, best condition, dan like new biasanya merupakan barang bekas pakai yang sudah digunakan oleh pemiliknya selama beberapa kali. Tanda-tanda bekas pemakaian biasanya tampak pada warna, sol luar, dan sol dalam untuk sepatu, dan warna serta kualitas kain untuk produk pakaian. Istilah like new, VGC, VVGC, dan sebagainya digunakan pedagang untuk mendeskripsikan bahwa barang dagangannya masih dalam kondisi sangat baik dan masih sangat layak pakai atau jual kembali. Kelengkapan bawaan pabrik, jika masih utuh dan lengkap, merupakan nilai tambah yang biasanya dapat mendongkrak harga barang itu.

Istilah suede on dan suede off mengacu kepada kondisi sepatu yang berbahan suede atau kulit hewan bagian dalam. Kulit yang digunakan sebagian besar kulit sapi. Kulit yang masih banyak bulu atau serabutnya dianggap on dan masih bagus. Sementara itu, kulit yang sudah gundul dianggap off atau mati. Harga jual sepatu bekas berbahan suede sangat dipengaruhi oleh kondisi suedenya. Semakin bagus kondisi suede, semakin tinggi harga sepatu itu. Harga sepatu berbahan suede anjlok tajam jika suede-nya sudah off apalagi mati.

Istilah cek reputasi di atas mengacu kepada cara untuk mengetahui apakah pedagang termasuk pedagang yang jujur dan amanah atau pedagang yang suka menipu. Dalam forum banyak orang yang berdagang hanya sebagai ajang keisengan saja. Bahkan, banyak yang berniat menipu. Salah satu cara untuk mengetahui apakah seorang pedagang dapat dipercaya, calon pembeli dapat menggunakan fitur cek reputasi.

Cek reputasi digunakan untuk menjaring opini atau testimoni dari anggota lain dalam grup yang sama yang pernah bertransaksi dengan pedagang itu. Pembeli yang merasa puas ketika bertransaksi dengan pedagang tersebut biasanya memberi kesaksian atau testimoni positif. Semakin banyak testimoni positif yang masuk, reputasi pedagang itu semakin baik. Namun, semakin banyak reputasi jelek apalagi negatif biasanya calon pembeli enggan melanjutkan transaksi dengan pedagang itu.

Cek reputasi sangat baik digunakan dalam konteks transaksi tansemuka karena pedagang dan pembeli tidak bertemu langsung. Jika reputasi seorang pedagang buruk atau belum bereputasi sama sekali, cara COD banyak ditempuh untuk menghindari hal-hal yang tidak diinginkan.

Pembeli dan pedagang juga sering menggunakan rekening bersama atau rekber untuk melanjutkan transaksi. Rekber mengacu kepada pihak ketiga yang menjembatani transaksi pedagang dan pembeli. Rekber dapat berupa orang pribadi atau situs marketplace semacam bukalapak dan tokopedia. Rekber akan menerima transfer uang dari pembeli dan meneruskan uang tersebut ke penjual jika transaksi sukses dan tidak ada keluhan dari pembeli. Penggunaan rekber sangat dianjurkan dalam konteks transaksi virtual seperti dalam grup jual-beli di Facebook. 
Tuah Talino

Tahun XIV Volume 14 Nomor 1 Edisi 31 Juli 2020

ISSN 0216-079X E-ISSN 2685-3043

Balai Bahasa Kalimantan Barat

Lelang ulang dikarenakan BNR

Ellesse remini the firm size L Minus hole 1 takasat mata

Kel zonk

tob :200k

$6 \mathrm{~kb}: 20,40,60 \mathrm{dst}$.

6 Format bid :nominal - lok - no wa

8 contoh : 620-bogor - 0896

CLOSE besok sore pukul 17:00(23-11-2018)

close sewaktu2 bisa dipercepat

Rules

dilarang bid \& run

6 cek saldo sebelum bid

6 batas tf $1 \times 4$ jam selebihnya bnr

6 BNR langsung jadi artis

6 Kirim' rekber siap

6 bid blm termasuk ongkir dri bogor

6 Cod hanya sekitar bogor/kirim kirim

6 pemenang akan saya hubungi no

(085719732630) selehihnva fake.

$>>L E L A N G L E L A N G A N \ll$

A. Saucony Jazz Black white size 42 kondisi used minus silahkan liat di pict ya.

B. Saucony Jazz Black White size 43 kondisi vGC used.

Noted : ada bonus di lelangan saya kali ini yaitu T-shirt JAKarta city Football size XL dan TShirt Atmosphere size XL bonus silahkan milih sendiri ya.

FORMAT BID :

Format Bid : Bid-Kota-No WA / Line.

Contoh:

A : 100-Jakarta-08991234567

B : 200-Bogor-089367825463

Keduanya Open Bid : 0k (Biar asik)

Kelipatan Bid : 20K, dst

Closed : malem ini jam 21.00 (Waktu Hp Saya)

Cod : Bintaro \& Jakarta selebihnya JNE,

End of bid semua exclude Ongkir

Cek isi dompet sebelum bid, cek saldo rekening

sebelum bid. NO BID \& RUN, NO REFUND!!!

Happy Bidding 
Tahun XIV Volume 14 Nomor 1 Edisi 31 Juli 2020

ISSN 0216-079X E-ISSN 2685-3043

Balai Bahasa Kalimantan Barat

\author{
Bismillah ... LELANG ! \\ Close lelang hari ini, kamis tanggal 22 \\ november 2018 jam 21:00 wib ( jam 9 \\ malam ) \\ Item : adidas samba OG stripe orange \\ Size : size $7.5 \mathrm{uk} / 41$ fit 42 \\ Kondisi : used, like a new ( $1 x$ dipake \\ match ) \\ Ex BNIBWT \\ Cek saldo/isi dompet \\ Rules: \\ -Ob: $100 \mathrm{~K}$ \\ -Kelipatan bid : $20 \mathrm{~K}$ (kelipatan) \\ -max bid $100 \mathrm{~K}$ \\ - Format bid : nominal-kota-kontak \\ -End of bid belum termasuk ongkos kirim \\ dari cikarang \\ - Cod my time my place \\ - Pemenang akan dihubungi melalui pm/wa \\ 081517266475 \\ -Max transfer $1 \times 15 j a m$ lewat dari itu \\ dianggap $\mathrm{BnR}$ \\ Happy bid Baca Lebih Sedikit \\ LELANG LELANG!!! \\ NAPAPIJRI RAINFOREST WINTER \\ Size:Xs fit M \\ Kondisi:Butuh Mandi \\ Minus: 2 hole kecil sama tag dalam ke cut \\ Kelengkapan:Jaket saja \\ Close:09:00 waktu hp saya 23 November 2018 \\ (bisa dipercepat) \\ Format: BID-KOTA-WA \\ Open Bid:100k \\ Kelipatan: 204060 dst (genap) \\ Max jump bid: bebas asal tanggung jawab \\ •bid yang sah akan saya like \\ -batas transfer $1 \times 12$ jam \\ -Dilarang keras BNR \\ -BNR cepet taubat \\ - Bid belum termasuk ongkir dari Batu-malang \\ -PEMENAN DIHUBUNGI NO 087860580747 \\ selain itu penipuu \\ Rekber? Siap,cek reput?dianjurin sangat
}


Untuk lebih menarik minat pembeli dan calon pembeli, pedagang atau secara umum anggota forum jual-beli biasanya mengadakan lelang secara berkala. Lelang biasanya diadakan setiap akhir pekan. Bagi pedagang, lelang biasanya dilakukan sebagai langkah terakhir supaya barang cepat laku. Risiko bagi pedagang ketika mengadakan lelang ialah kerugian yang cukup besar. Konsekuensi kerugian ini berpotensi terjadi ketika nilai akhir lelang tidak sesuai dengan yang diharapkan. Namun, ada kalanya pula pedagang mendapatkan keuntungan besar jika barang yang dilelang unik, langka, dan banyak peminatnya.

Sebaliknya dalam lelang, pembeli dan calon pembeli memiliki banyak keuntungan. Pembeli bisa mendapatkan barang dengan harga jauh di bawah harga pasar. Namun, jika ternyata peminatnya membeludak dan banyak tawaran yang masuk, harga barang berpotensi melambung. Hal inilah yang kadang-kadang menimbulkan kasus-kasus pascalelang yang merugikan pedagang.

Contoh foto layar di atas memperlihatkan empat aktivitas lelang. Banyak istilah dan register yang digunakan di sana. Yang pertama ialah BNR. BNR merupakan kependekan dari bid and run. Dalam kamus bahasa Inggris kata bid mengacu kepada kegiatan menawar, sedangkan run secara kontekstual dimaknai sebagai tidak bertanggung jawab.

Dalam kegiatan lelang ada kalanya penawar atau bidder sekadar iseng atau tidak bersungguh-sungguh dalam menawar suatu barang yang dilelang. Penawar seperti inilah yang biasanya menjadi pelaku BNR. Harga yang diajukannya sebenarnya merupakan tawaran tertinggi sehingga dia keluar sebagai pemenang lelang. Namun, karena berbagai hal, di antaranya ketidaksungguhan tadi, ia tidak melanjutkan transaksi. Kasus BNR seperti ini sangat sering terjadi sehingga pedagang biasanya terpaksa melakukan lelang ulang.

Pelaku BNR sering pula menjadi artis dadakan. Dalam klausul atau ketentuan lelang biasanya dicantumkan "BNR jadi artis". Makna kontekstual dari ungkapan ini ialah identitas pelaku BNR akan disebarluaskan dan disosialisasikan kepada seluruh grup, bahkan hingga di luar grup tempat pedagang melakukan lelang. Konsekuensinya ialah pelaku BNR akan mendapatkan hukuman sosial berupa black list atau yang paling berat tidak diperkenankan ikut kegiatan apa pun di grup itu. Sering pula admin grup mengeluarkan pelaku BNR dari grup untuk menjaga kondusivitas grup. Karena keterkenalannya inilah kemudian pelaku BNR disebut sebagai artis.

Ketika melakukan lelang, pedagang berkewajiban mendeskripsikan barang lelangannya sedetail mungkin disertai foto yang beresolusi tinggi. Hal itu dilakukan supaya tidak ada komplain di kemudian hari dari pembeli. Penawar, dalam hal ini berpotensi sebagai pembeli dan calon pembeli, ketika mengajukan bid, secara tidak langsung dianggap menerima kondisi barang.

Beberapa istilah yang sering digunakan dalam mendeskripsikan kondisi barang ialah zonk, minus, dan judge by picture. Istilah zonk mengacu kepada jargon salah satu acara kuis televisi yang mendeskripsikan keadaan tertentu ketika peserta tidak mendapatkan hadiah apa pun. Kelengkapan zonk yang dimaksud dalam konteks ini ialah barang tidak memiliki kelengkapan bawaan apa pun. Kelengkapan berupa boks, kertas pembungkus, label, dan rekatan untuk sepatu 
Tuah Talino

Tahun XIV Volume 14 Nomor 1 Edisi 31 Juli 2020

ISSN 0216-079X E-ISSN 2685-3043

Balai Bahasa Kalimantan Barat

serta plastik dan label gantung untuk pakaian tidak disertakan dalam lelang. Kelengkapan tersebut dapat dengan sengaja tidak ikut dilelang atau memang sudah dibuang. Dalam konteks ini, pembeli hanya akan memperoleh barang tesrebut dan biasanya disertai dengan boks atau dus pengganti.

Istilah minus mengacu kepada cacat barang dan kondisi barang setelah dipakai selama beberapa waktu. Barang, dalam hal ini sepatu atau pakaian, tentu menurun kualitas dan kondisinya seiring dengan pemakaian. Warna yang menurun dan tidak pekat lagi, sobek, berlubang, dan sebagainya wajib dideskripsikan pedagang ketika menawarkan barang dagangannya.

Seperti dijelaskan di atas, istilah minus ini sering bias ketika subjektivitas antara pedagang dan pembeli atau calon pembeli berbeda. Minus menjadi istilah yang relatif atau nisbi. Warna yang turun bisa saja tidak dianggap minus oleh pedagang, tetapi kondisi wajar karena pemakaian. Penilaian pembeli dapat berbeda. Minus inilah yang sering menimbulkan ketidakpuasan pembeli atas barang yang diperolehnya, apalagi jika pembeli dan pedagang, dan ini sering terjadi, tidak bisa bertemu muka. Jika kondisi memungkinkan, bersemuka dengan pedagang sangat dianjurkan. Mereka menamai ini sebagai COD.

Istilah COD merupakan kependekan dari cash on delivery atau biaya pengiriman ditanggung oleh penerima barang. Istilah COD dalam konteks ini dimaknai sebagai aktivitas pedagang dan pembeli bertemu muka sehingga dapat melihat dan menilai secara langsung kondisi barang. COD sangat dianjurkan untuk mengantisipasi adanya ketidakpuasan di kemudian hari yang berakibat pada adanya sanksi sosial.

Pembeli pun tidak begitu saja terbebas dari sanksi sosial semacam ini. Pedagang yang merasa dibohongi pembeli, pembeli yang terlalu mengada-ada, dan sebagainya juga dapat menjadi bahan bagi pedagang untuk menjatuhkan sanksi sosial. Dalam konteks ini, karena sebagin besar interaksi dilakukan secara tidak langsung, kejujuran dan keterbukaan kedua belah pihak sangat penting.

Istilah judge by picture mengacu kepada anjuran pedagang kepada pembeli dan calon pembeli untuk menilai barang dagangannya hanya lewat foto. Jika membeli barang tersebut, pembeli dianggap setuju dan menerima kondisi barang itu. Dalam hal ini, jika transaksi dilanjutkan, komplain atau protes pembeli kepada pedagang sudah tidak layak lagi diajukan.

Dalam kegiatan lelang istilah $\mathrm{OB}, \mathrm{KB}$, dan jump bid sering dipakai. $\mathrm{OB}$ merupakan kependekan dari own bid dan mengacu kepada tawaran awal pedagang terhadap barang lelangan. OB ini dapat dikatakan sebagai tawaran awal lelang atau nilai minimal lelang. Pedagang biasanya mencantumkan OB 0 rupiah supaya lelang berjalan dengan semarak. Namun, dengan pertimbangan tertentu, pedagang dapat mengajukan OB sebesar ratusan ribu atau bahkan jutaan rupiah. Hal itu dilakukan pedagang untuk mengetahui bahwa peminat lelang merupakan orangorang yang memang benar-benar serius dan ingin membeli dan memiliki barang yang dilelang tersebut. Cara ini juga dinilai efektif untuk menghalau para pelaku BNR yang sering tidak bertanggung jawab usai menang lelang.

KB merupakan kependekan dari kelipatan bid dan mengacu kepada kelipatan tawaran yang diajukan pembeli. KB biasanya berkisar dari sepuluh, dua puluh, lima puluh ribu, hingga jutaan rupiah. Pembeli kemudian menerapkan KB 
Tuah Talino

Tahun XIV Volume 14 Nomor 1 Edisi 31 Juli 2020

ISSN 0216-079X E-ISSN 2685-3043

Balai Bahasa Kalimantan Barat

dalam nilai tawaran yang diajukannya dimulai dari OB yang ditetapkan oleh pedagang. Jika OB 100 ribu rupiah dan KB 20 ribu rupiah, nilai yang dibolehkan untuk diajukan ialah 120 ribu rupiah, 140 ribu rupiah, 160 ribu rupiah, dan seterusnya.

Istilah jump bid mengacu kepada loncatan tawaran dengan tentu saja masih berpedoman pada KB yang ditetapkan pelelang atau pedagang. Pembeli dan calon pembeli dapat menawar barang dengan tidak melanjutkan KB milik penawar sebelumnya, tetapi langsung menawar dengan harga lebih tinggi. Misalnya, nilai tawar sebelumnya 200 ribu rupiah dengan KB 20 ribu rupiah. Pembeli dapat mengajukan jump bid senilai 300 ribu rupiah. Nilai maksimal jump bid juga biasanya ditetapkan oleh pelelang atau pedagang.

Berkaca pada uraian di atas, dalam beberapa level dan ranah, bahasa dapat menjadi pembeda dan pembatas antarkomunitas. Komunitas satu dibedakan dari komunitas lain berdasarkan, salah satunya, bahasanya. Bahasa pun dapat menciptakan eksklusivitas dan inklusivitas. eksklusivitas dan inklusivitas di sini dimaksudkan apakah komunitas yang memakai bahasa itu tertutup atau terbuka.

Komunitas pedagang dan pembeli dengan minat yang sama dalam FJBIC dan FJBCCI juga dapat dikatakan sebuah komunitas yang tertutup. Dinamai tertutup karena aktivitas dan bahasa atau istilah yang digunakan oleh kelompok ini jarang diketahui oleh orang banyak. Untuk menjadi anggota grup itu pun harus mendaftar terlebih dahulu.

Beberapa hal dapat disimpulkan berdasarkan analisis di atas. Yang pertama ialah bahasa yang digunakan dalam sebuah grup atau komunitas, dalam hal ini FJBIC dan FJBCCI, agak berbeda dengan bahasa masyarakat umum, khususnya dalam tataran istilah yang berhubungan dengan minat dan kesenangan mereka. Istilah atau register ini mereka gunakan secara intensif sebagai alat bergaul, berinteraksi, dan bertransaksi antarsesama anggota grup. Orang luar yang bukan anggota grup sekadar bisa membayangkan dan menerka-nerka apa makna percakapan yang menggunakan register tersebut. Jika ingin mengetahui makna register atau istilah yang dipakai mau tidak mau ia harus "menceburkan diri" atau dengan kata lain menjadi bagian dari grup itu.

Kesamaan minat dan ideologi, dalam hal ini kesenangan dan hobi, membentuk mereka menjadi komunitas tersendiri yang akhirnya menimbulkan kebanggaan sekaligus saling bergantung antarsesama anggota grup. Pertalian kekerabatan kemudian terjalin cukup erat seiring meningkatnya intensitas interaksi antarmereka. Untuk menambah akrab dan mengekslusifkan diri ini kemudian register atau istilah-istilah khusus itu terbentuk dan digunakan.

\section{PENUTUP}

Bahasa merupakan pembeda. Dengan kata lain, ragam istilah dan register yang digunakan oleh komunitas FJBIC dan FJBCCI digunakan untuk membedakan komunitas mereka dari komunitas lain. Hal ini penting mengingat bahasa ialah lambang jati diri seseorang dan lambang jati diri sebuah kelompok.

Berdasarkan analisis dan perian data yang ditampilkan di atas, penulis menggolongkan beberapa jenis istilah dan register berdasarkan bentuknya. Beberapa istilah berbentuk singkatan yang berasal dari istilah bahasa asing, 
Tuah Talino

Tahun XIV Volume 14 Nomor 1 Edisi 31 Juli 2020

ISSN 0216-079X E-ISSN 2685-3043

Balai Bahasa Kalimantan Barat

seperti WTS, WTB, dan sebagainya; istilah lain berbentuk kata asing seperti give away, mint condition, very near dead stock, dan sebagainya.

Istilah dan register itu dalam sebuah komunitas yang dibangun di atas kepentingan, minat, dan ideologi yang sama dijadikan perekat kelompok itu. Ciriciri perekat itu kemudian menjadi pembeda kelompok itu dari kelompok lainnya. Mereka yang berada dalam komunitas jual-beli, misalnya, memiliki kesenangan dan minat yang sama yang menyatukan dan mengelompokkan mereka dan menjadikannya berbeda dari yang lain.

Sebagai sebuah komunitas di dunia maya, FJBIC dan FJBCCI dapat menjadi wadah berinteraksi, berdiskusi, berkomunikasi, dan bertransaksi antarsesama anggota. Interaksi dan komunikasi di sini ialah dalam konteks berbagi informasi mengenai minat dan kegemaran mereka akan hal atau benda yang sama. Transaksi mengacu kepada tidak hanya perniagaan, dalam hal ini jualbeli, tetapi pertukaran barang tanpa uang pun sering terjadi.

Penulis kemudian menyarankan diadakannya penelitian lebih lanjut berkenaan dengan bahasa di media sosial, baik yang bersifat komunal, transaksional, maupun hal-hal lain yang terjadi dalam media sosial. Bahasa dalam media sosial sangat beragam. Oleh karena itu, pemilihan topik yang spesifik dan mutakhir akan dapat mengidentifikasi seperti apa cermin bahasa komunitas tertentu di media sosial.

\section{DAFTAR PUSTAKA}

Atmahardianto, C. (2010). Register dalam Komunitas Dunia Maya Kaskus. Retrieved October 31, 2018, from www.dglib.uns.ac.id/pengguna.php?mn=showview\&id=25660

Chambers, J. K. (2001). Sociolinguistics Theory. Oxford: Blackwell.

Creswell, J. W. (2003). Research Design: Qualitative, Quantitative and Mixed Method Approach. California: Sage Publications.

Dhianari, N. M. (2011). Ragam Bahasa Kaskus (Universitas Udayana). Retrieved from www.pps.unud.ac.id/thesis/detail-276-ragam-bahasa-kaskus.html

Halliday, M. A. K., \& Hasan, R. (1992). Bahasa, Konteks, dan Teks; Aspek-aspek Bahasa dalam Pandangan Semiotik Sosial. Yogyakarta: UGM Press.

Karindra, A. P. (2011). Perilaku Komunikasi Interpersonal pada Kaskuser dengan Kecenderungan Internet Addiction Disorder (Universitas Negeri Malang). Retrieved from www.karya-ilmiah.um.ac.id/index.php/BKPsikologi/article/view/14736

Muttaqien, Z. (2016). Jargon Komunitas Jual-Beli Jersey di Internet. Prosiding International Seminar Prasasti III, 455-460. Surakarta.

Saville-Troike, M. (1989). The Ethnography of Communication. Oxford: Blackwell.

Sudaryanto. (2015). Metode dan Aneka Teknik Analisis Bahasa. Yogyakarta: Sanata Darma University Press.

Sumarsono, \& Partana, P. (2002). Sosiolinguistik. Yogyakarta: Pustaka Pelajar dan Sabda. 
Tuah Talino

Tahun XIV Volume 14 Nomor 1 Edisi 31 Juli 2020

ISSN 0216-079X E-ISSN 2685-3043

Balai Bahasa Kalimantan Barat

Suyanto, B., \& Sutinah. (2005). Metode Penelitian Sosial: Berbagai Alternatif Pendekatan. Jakarta: Kencana.

Thufail, M. D. (2017). Register Jual-Beli Handphone di Media Sosial Facebook. Universitas Negeri Semarang.

Wijana, I. D. P., \& Rohmadi, M. (2006). Sosiolinguistik. Yogyakarta: Pustaka Pelajar. 